\title{
Evaluation of Roseola Infantum Cases in Terms of Demographic Properties and Laboratory Values*
}

\author{
Roseola Infantum Olgularinın Demografik ve \\ Laboratuvar Değerleri Açısından Değerlendirilmesi
}

\author{
Zafer Bıçakçı1', Muhammet Hafit Arvas², Canozan Biçer², Ahsen Akay², Sefer Üstebay², Döndü Ülker Üstebay² \\ 'Pediatric Hematology Unit, Kafkas University School of Medicine, Kars, Turkey \\ ${ }^{2}$ Department of Pediatric Health and Diseases, Kafkas University School of Medicine, Kars, Turkey
}

* This article was presented as a poster at the $5^{\text {th }}$ Children's Friends Congress held in Istanbul between 06-08 March 2017.

\section{Abstract}

Objective: To share our experince from demographic and labaratory results of 46 patients who applied to our policlinic with complaints of fever and rash and diagnosed as roseola infantum between 2012-2016.

Material and Methods: Labaratory and demographic findings of 41 patients who diagnosed as roseola infantum clinically had been evaluated. Roseala infantum cases were diagnosed as 10 mo old infant with high temperature over three days and nontoxic maculopapuller rash on the trunk and after making differential diagnosis of other diseases that courses with skin rash and high body temperature. Neutrophil counts between 0-500, 500-1000 and 1000-1500 were accepted as high, medium and low, respectively.

Results: 25 of the patients were female (54.3\%), 21 of them were male (45.7\%), mean age was $11.5 \pm 7.02$ (3-36 months) and peak age of onset was 9-11 months. $76 \%$ of patients were (35/46) under one years of age. Disease was seen all year round but it was seen least at September and October and was seen mostly at December. Mean labaratory leves were found as: $\mathrm{Hb} 11.8 \pm 0.97 \mathrm{~g} / \mathrm{L}, \mathrm{HCT} 35.0 \% \pm 3.2, \mathrm{MCV} 73.7 \pm 5.10$ $\mathrm{fL}$, platelet count $299 \pm 128.8 \times 10^{9} / \mathrm{L}$, leukocyte count $7.6 \pm 2.8 \times 10^{9} / \mathrm{L}$, neutrophil count $1.7 \pm 1.30 \times 10^{9} / \mathrm{L}$, lymphocyte count $5.0 \pm 2.2 \times 10^{9} / \mathrm{L}$, mean C-reactive protein $4.0 \pm 4.5 \mathrm{mg} / \mathrm{L}$, AST $50 \pm 14.8 \mathrm{U} / \mathrm{L}, \mathrm{ALT} 24 \pm 10.7$ U/L, LDH $385 \pm 96.6 \mathrm{U} / \mathrm{L}$. $57.5 \%$ of the patients had neutropenia (10\% severe, $35 \%$ moderate and $12.5 \%$ mild) and neutropenia resolved in one months. Mean lymphocyte/neutrophil rate was calculated as 2.94 (relative lymphocytosis). None of the patients experienced infections secondary to neutropenia and febrile convulsion.
Özet

Giriş: Bu çalışmanın amacı 2012-2016 yılları arasında yüksek ateş, döküntü nedeniyle polikliniğimize başvuran klinik olarak roseola infantum tanısı konan 46 hastanın demografik ve laboratuvar bulgularından edinilen deneyimi paylaşmaktır.

Gereç ve Yöntemler: Klinik olarak roseola infantum tanısı konan 41 hastanın laboratuvar ve demografik bulguları değerlendirildi. Hastalığın tanısı ateş ve döküntüye neden olabilecek diğer hastalıkların ayırıcı tanısı yapıldıktan sonra, "üç günden beri devam eden yüksek ateş, toksik olmayan 10 aylık bir bebeğin gövdesinde makülopapüler döküntü" olması roseola infantum olarak değerlendirildi. Nötrofil sayısı 0-500 ise ağır, 500-1000 ise orta, 1000-1500 ise hafif nötropeni olarak değerlendirildi.

Bulgular: Hastaların 25 (\%54.3)'i kız, 21 (\%45.7)'i erkek, yaş ortalaması $11.5 \pm 7.02$ (3-36 ay) ve başlangıç pik yaşı 9-11 ay idi. Hastaların \%76'sı (35/46) bir yaşın altında idi. Hastalık tüm yıl boyunca görülmekle birlikte en az Eylül ve Ekim ayında, en çok Aralık ayında gözlendi. Hastaların sırasıyla ortalama Hb $11.8 \pm 0.97 \mathrm{~g} / \mathrm{L}, \mathrm{HCT} \% 35.0 \pm 3.2, \mathrm{MCV} 73.7 \pm 5.10$ $\mathrm{fL}$, trombosit sayısı $299 \pm 128.8 \times 10^{9} / \mathrm{L}$, lökosit sayısı $7.5 \pm 2.8 \times 10^{9} / \mathrm{L}$, nötrofil sayısı $1.7 \pm 1.30 \times 10^{9} / \mathrm{L}$, lenfosit sayısı $5.0 \pm 2.2 \times 10^{9} / \mathrm{L}$, ortalama C-reaktif protein (CRP) değeri $4.0 \pm 4.5 \mathrm{mg} / \mathrm{L}, \mathrm{AST} 50 \pm 14.8 \mathrm{U} / \mathrm{L}, \mathrm{ALT} 24 \pm$ $10.7 \mathrm{U} / \mathrm{L}, \mathrm{LDH} 385 \pm 96.6 \mathrm{U} / \mathrm{L}$ olarak bulundu. Hastaların \%57.5'inde nötropeni (\%10 ağır, \%35 orta ve \%12.5 hafif) vardı. Ortalama lenfosit/nötrofil oranı 2.94 (rölatif lenfositoz) olarak hesaplandı. Hastaların hiçbirinde nötropeniye sekonder enfeksiyon ve febril konvülzyon gözlenmedi.

Sonuç: Nötropeni, relatif lenfositoz, hafif AST yüksekliği ve CRP negatifliği saptanan üç yaşın altındaki çocuklarda (özellikle bir yaşın altındaki
Correspondence Address / Yazışma Adresi

Zafer Bıçakçı

Kafkas Üniversitesi Tıp Fakültesi, Çocuk Sağlığı ve Hastalıkları Anabilim Dalı,

Çocuk Hematolojisi Ünitesi, Kars-Türkiye

E-mail: zaferbicakcib@yahoo.com.tr OCopyright 2017 by Pediatric
Infectious Diseases Society -Available online at www.cocukenfeksiyon.org ○Telif Hakkı 2017 Çocuk Enfeksiyon Hastalıkları Derneği -Makale metnine www.cocukenfeksiyon.org web sayfasından ulaşılabilir 
Conclusion: Under three years of age children (especially young infants) with fever without source accompanying neutropenia, relative lymphocytosis, mild AST elevation and negative CRP roseola infantum should be considered as an etiological factor.

Keywords: Fever, C-reactive protein, relative lymphocytosis, roseola infantum, transient neutropenia

\section{Introduction}

Roseola infantum is an acute viral infection, particularly observed in infants and play-age children and characterized by clinical manifestations of fever of unknown origin and widespread maculopapular rashes which develop following reduction in the fever. Human herpesvirus (HHV) -6 and HHV7 (approximately two-third, HHV-6 and one-fourth, HHV-7) are responsible for most cases of Roseola infantum. Two different variants of HHV-6, namely HHV-6A and B differ in terms of their genetic, biological, and immunological properties. Almost all HHV-6B (more than 99\%) produce a clinical picture of roseola infantum, while HHV-6A constitutes the majority of childhood infections in some African communities (1-3).

Patients with roseola infantum present with a clinical picture of fever of unknown origin, and it may be difficult to make a differential diagnosis at baseline. Diagnosis is usually made after the patient's typical course has been observed $(4,5)$. Acute HHV-6 infection is responsible for $20 \%$ of children who come to the emergency department due to febrile illness among 6-8 months old children. About $13 \%$ of these children are hospitalized (6). These findings point to an important economics of HHV- 6 infection and emphasize the importance of making the right differential diagnosis to avoid unnecessary antibiotic use. As a result, it may be worthwhile to develop a quick, simple test for this self-limiting infectious disease, without applying unnecessary treatment and/or expensive laboratory tests (7).

In acute phase response, the synthesis of a number of proteins is under the control of cytokines originating from the site of the pathology and the synthesis of these proteins is particularly fast in the liver (8). This response is proportional to the severity of the inflammatory stimulus and is mediated by proinflammatory cytokines such as interleukin (IL)-6, IL-1, tumor necrosis factor-alpha (TNF- $a$ ) and interferon-gamma $($ INF- $\gamma$ ). Fever is also one of the acute phase responses to infection or inflammation through proinflammatory cytokines. CRP, another product of acute phase response, is produced primarily by the liver in response to cytokines, primarily IL- 6 (9). Although HHV- 6 is a potent stimulator of TNF- $\alpha$ and IL-1 $\beta$ in peripheral blood mononuclear cell cultures, HHV- 6 has no effect on IL-6 synthesis. This may be the reason why the CRP bebeklerde) kaynağı saptanamayan ateş nedeni olarak roseola infantum da akla gelmelidir.

Anahtar Kelimeler: Ateş, C-reaktif protein, geçici nötropeni, relatif lenfositoz, roseola infantum

level does not increase as an acute phase reactant despite the presence of fever during HHV-6 infection (10). Transient neutropenia has also been reported in primary HHV- 6 infection $(10,11)$. In addition to the inability to synthesize IL-6, which stimulates neutrophil production during primary HHV-6 infection, the suppression of bone marrow progenitor cells may also be responsible for transient neutropenia (12-14).

HHV- 6 antigens, nucleic acids and antibodies are used in the detection of viral infection. At the time of initial evaluation, there is no definite diagnostic, easily distinguishable, or sufficiently specific clinical or laboratory finding for HHV-6 primary infection (15). Since tests used for the definitive diagnosis of the disease take a certain amount of time to produce results, it can be considered as a non-practical approach to the immediate emergency diagnosis of the patient. As a result, some hematological laboratory values considered to be more practical than predicting the disease (roseola infantum) in emergency conditions, may act as a clue.

In the present study, we aimed to evaluate the demographic and laboratory findings of patients who had a pre-clinical diagnosis of roseola infantum in our polyclinic due to high fever/rash, and to identify findings which would be useful for a rapid diagnosis of the condition.

\section{Materials and Methods}

Data of this descriptive study were obtained from $46 \mathrm{pa}-$ tients who visited our outpatient clinic between the period of 2012-2016 and who were pre-diagnosed with roseola infantum.

\section{Information Obtained From Files}

Pre-diagnosis of the disease, age of the patient, gender, season during which it was reported, hemoglobin $(\mathrm{Hb})$, hematocrit $(\mathrm{HCT})$, mean corpuscular volume (MCV), total platelet count, total leukocyte, neutrophil count, lymphocyte count, C-reactive protein, aspartate aminotransferase (AST), alanine aminotransferase (ALT) and lactate dehydrogenase (LDH) values were used. The laboratory data of five patients were not found in the files. As a result, demographic and seasonal characteristics were evaluated on 46 patients whereas laboratory characteristics were evaluated on 41 patients. 


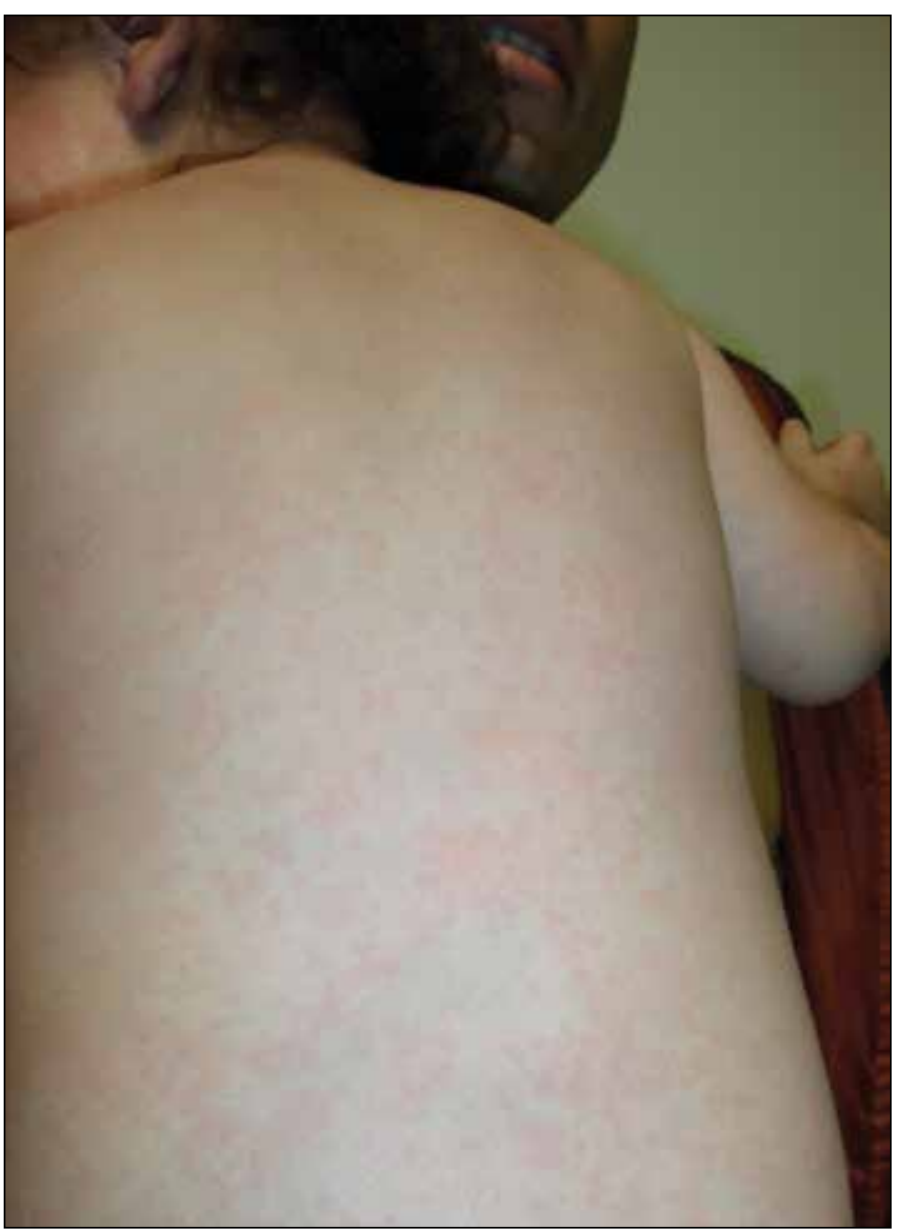

Picture 1. Typical maculopapular eruptions in the torso of a child with roseola infantum.

\section{Definitions of Variables}

The diagnosis of roseola infantum was made from the "high fever that lasted for three days, and maculopapular rash on the chest of a 10-month-old non-toxic baby" after making a differential diagnosis from other diseases that may cause fever and rash (Picture 1) (5).

A neutrophil count of 0-500 was evaluated as severe, 5001000 as moderate and $1000-1500$ as mild neutropenia (10).

Low risk criteria was defined as: laboratory findings which did not show any indication for a risk of severe bacterial infection, a leukocytes count of between $5-15.000 / \mathrm{mm}^{3}$ from the complete blood count, bands count of less than $1.500 / \mathrm{mm}^{3}$, and C-reactive protein of less than $20 \mathrm{mg} / \mathrm{L}(16,17)$.

High-risk criteria was defined as: laboratory findings which indicated a risk of severe bacterial infections, a leukocyte count of less than $5.000 / \mathrm{mm}^{3}$ or above $15.000 / \mathrm{mm}^{3}$ or bands count of more than $1.500 / \mathrm{mm}^{3}$, from the complete blood count, and C-reactive protein of more than $20 \mathrm{mg} / \mathrm{L}(16,18)$.

\section{Statistical Analysis}

SPSS package program (IBM, Chicago, USA) was used for the statistical calculations of this research. Frequencies, persentages, measures of central tendency (mean and median values) and measures of variability (standard deviation, minimum and maximum values) were used in this study.

\section{Results}

Twenty-five $(54.3 \%)$ of the patients were female while $21(45.7 \%)$ were male. The mean age was found to be $11.5 \pm$ 7.02 (3-36 months), while the median age was 10.0 months. The baseline peak age of the disease was 9-11 months. Seventy-six percent (35/46) of the patients were under one year of age (Figure 1). The disease was observed throughout the year, least in September and October, but mostly observed in December (Figure 2). Forty-one of the patients had laboratory data (Table 1). Neutropenia was detected in $57.5 \%$ (23 patients) of the 40 patients with neutrophil values. Neutropenia was reported to be severe in $10.0 \%(n=4)$ of the patients, moderate in $35 \%(n=14)$ and mild in $12.5 \%(n=5)$ of the patients (Table 2). Neutropenia improved within a period of about one month. The mean lymphocyte/neutrophil ratio was calculated as 2.94. None of the patients reported secondary infection and febrile seizures to neutropenia. All of our patients had low risk criteria for infection.

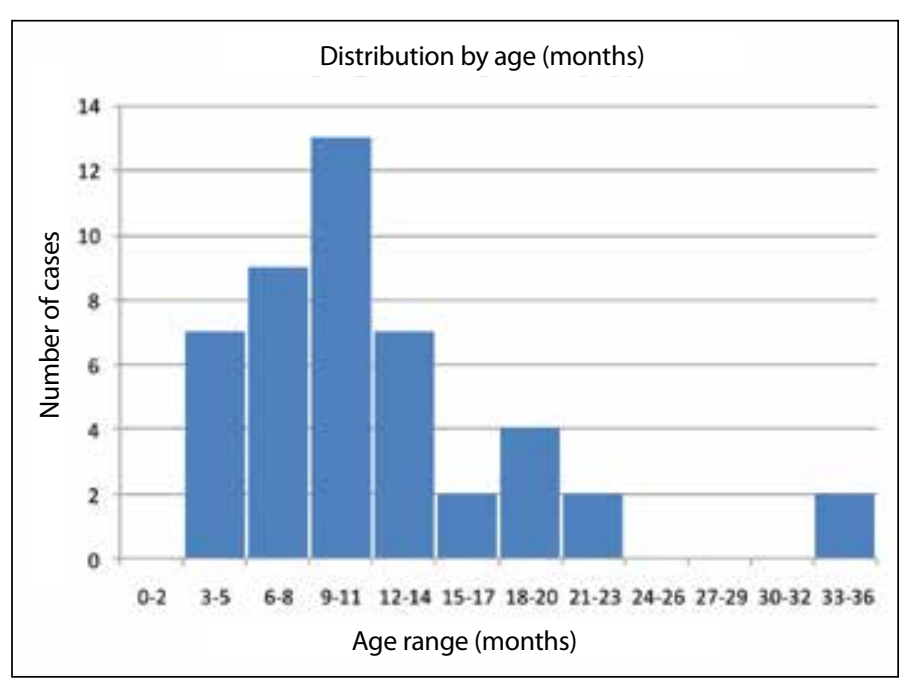

Figure 1. According to the age chart, there was a rapid increase in the number of cases from 3 months till between 9-11 months, followed by a relatively slower decline from 21-23 months. 


\begin{tabular}{|c|c|c|c|c|c|c|}
\hline I & 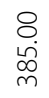 & 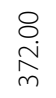 & $\begin{array}{l}8 \\
\stackrel{0}{\circ}\end{array}$ & $\frac{8}{\stackrel{8}{\sim}}$ & 怘 & \\
\hline 㱑 & $\begin{array}{l}\stackrel{8}{+} \\
\stackrel{+}{\sim}\end{array}$ & $\frac{8}{\grave{\sim}}$ & $\begin{array}{l}\stackrel{尺}{2} \\
\stackrel{0}{0}\end{array}$ & $\underset{i}{8}$ & $\frac{8}{\overline{6}}$ & 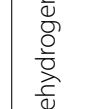 \\
\hline 战方 & : & $\begin{array}{l}8 \\
\text { \&े }\end{array}$ & 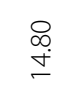 & $\begin{array}{l}8 \\
\text { শं }\end{array}$ & $\frac{8}{8}$ & 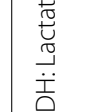 \\
\hline 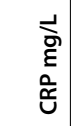 & 웅 & $\stackrel{\sim}{\widetilde{O}}$ & $\stackrel{\text { fn. }}{0}$ & $\bar{\circ}$ & $\underset{i}{\stackrel{8}{i}}$ & 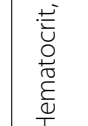 \\
\hline $\begin{array}{l}\overline{\overline{\bar{z}}} \\
\bar{o} \\
\overline{\bar{c}} \\
\overline{\mathrm{u}}\end{array}$ & $\stackrel{\circ}{\circ}$ & $\stackrel{\circ}{\circ}$ & $\frac{\Delta}{0}$ & ㅇ. & 占 & 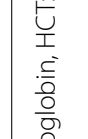 \\
\hline $\begin{array}{l}\overline{\overline{\bar{z}}} \\
\bar{O} \\
\bar{O} \\
\bar{\Phi} \\
\bar{\infty}\end{array}$ & $\stackrel{\infty}{\circ}$ & 号 & ठ̊. & \&. & J & 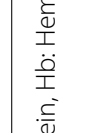 \\
\hline 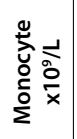 & กี & 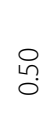 & 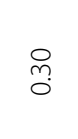 & $\frac{m}{0}$ & $\stackrel{\infty}{\underset{\sim}{\sim}}$ & 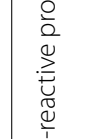 \\
\hline 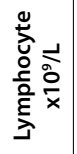 & in & ผี & $\underset{\sim}{\sim}$ & $\stackrel{+}{\leftarrow}$ & $\underset{\beth}{\simeq}$ & 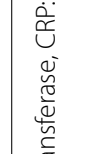 \\
\hline 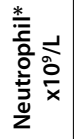 & 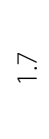 & 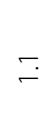 & $\stackrel{m}{\longrightarrow}$ & กั & $\underset{\check{n}}{\check{E}}$ & 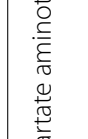 \\
\hline 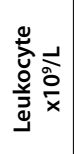 & $\stackrel{n}{n}$ & $\stackrel{\curvearrowright}{\wedge}$ & $\stackrel{\infty}{\sim}$ & $\stackrel{\infty}{\sim}$ & $\stackrel{\sim}{\sim}$ & 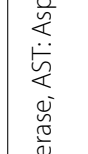 \\
\hline 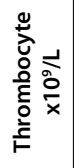 & 일 & $\begin{array}{l}\stackrel{0}{0} \\
\stackrel{\nabla}{v}\end{array}$ & $\begin{array}{l}\infty \\
\infty \\
\stackrel{\infty}{\simeq}\end{array}$ & 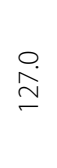 & $\stackrel{\circ}{\prod_{\infty}}$ & 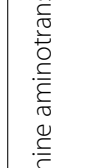 \\
\hline$\sum_{\Sigma}^{L}$ & 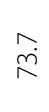 & $\hat{\sim}$ & $\overline{i n}$ & $\frac{0}{6}$ & $\underset{\infty}{\stackrel{+}{i}}$ & 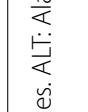 \\
\hline$\stackrel{\circ}{\stackrel{\circ}{x}}$ & 囟 & $\begin{array}{l}\dot{0} \\
\dot{m}\end{array}$ & $\stackrel{\sim}{m}$ & Ð & $\stackrel{\stackrel{v}{\forall}}{\stackrel{\forall}{*}}$ & 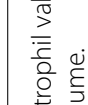 \\
\hline 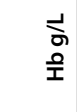 & $\stackrel{\infty}{=}$ & $\stackrel{\circ}{\stackrel{i}{I}}$ & ò & ๙઼ & $\check{\check{\Xi}}$ & 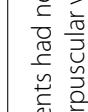 \\
\hline & $\begin{array}{l}\stackrel{\ulcorner}{\widetilde{\varpi}} \\
\stackrel{\mathbb{N}}{z}\end{array}$ & $\begin{array}{l}\frac{\sqrt{0}}{\overline{0}} \\
\stackrel{0}{\Sigma}\end{array}$ & 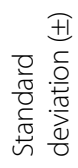 & 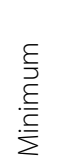 & 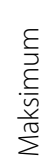 & 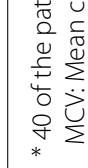 \\
\hline
\end{tabular}

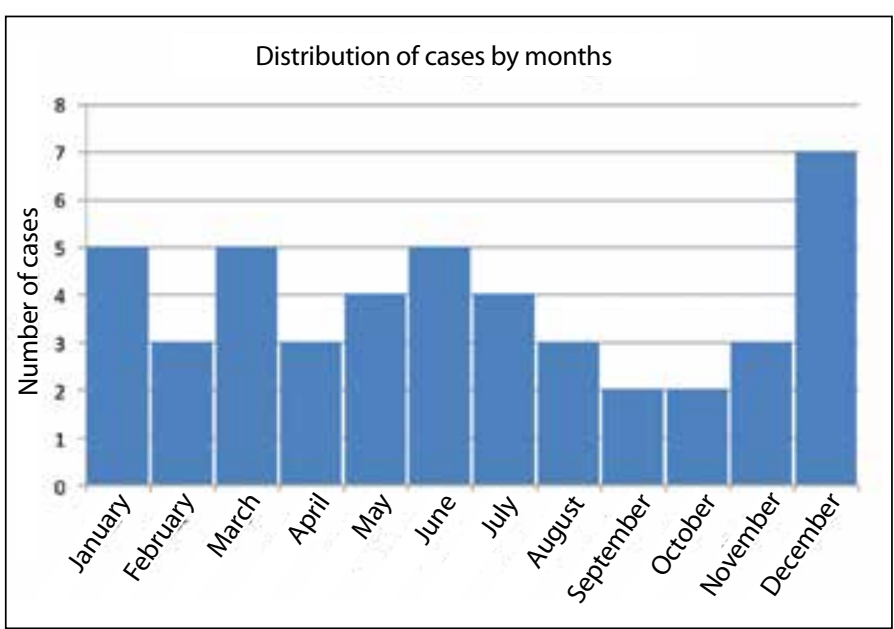

Figure 2. The disease was observed throughout the year, least in April and September, but mostly observed in December.

Table 2. Mean neutrophil counts and percentages of patients

\begin{tabular}{|l|c|c|}
\hline Neutrophil count & $\begin{array}{c}\text { Number of } \\
\text { patients }\end{array}$ & Percentage \% \\
\hline $0-500$ & 4 & 10.0 \\
\hline $500-1000$ & 14 & 35.0 \\
\hline $1000-1500$ & 5 & 12.5 \\
\hline$>1500$ & 17 & 42.5 \\
\hline Total & 40 & 100 \\
\hline
\end{tabular}

\section{Discussion}

The most common finding in children with HHV- 6 primary infection is fever (19). The disease starts suddenly with a fever. The fever may rise up to $\geq 40^{\circ} \mathrm{C}$. Symptoms of mild upper respiratory tract infection and cervical lymphadenopathy may coexist. The fever persists for 3-5 days without a typical finding for the disease. Febrile convulsions may be observed during this period. The overall appearance of the patient is relatively good, although the fever may be high. Fever falls on the $3^{\text {rd }}$ $5^{\text {th }}$ days in the form of crises, and macular or maculopapular eruptions start appearing from the body (torso), spreading to the arms, neck, face and legs, as the fever returns to normal. The eruptions are short-lived, rarely lasting for more than 24 hours (1).

Patients with roseola infantum present with a clinical picture of fever of unknown origin, and it may be difficult to make a differential diagnosis at baseline. Diagnosis is usually made after the patient's typical course has been observed $(4,5)$. Approximately $58-98 \%$ of children with HHV- 6 infection have fever, and about $17-98 \%$ has been reported to have eruptions of 
roseola infantum. The reasons for these varying percentages can be explained by the existence of different research layouts, differences in inclusion research criteria, geographical differences and the presentation of different tropism of various viral types $(19,20)$. Although roseola infantum is often a benign disease which is self-restricting, the diagnosis of roseola infantum may be made by excluding the other more serious disorders that cause fever and skin eruptions. In addition, the maculopapular skin eruption in the non-toxic 10-monthsold baby's torso, with symptoms of high-fever suggests the diagnosis of roseola infantum (5). Clinical diagnosis in all of our patients was made after observation of post-fever classical/typical roseola infantum eruptions, the presence of low risk criteria in the laboratory analysis, and after excluding the other diseases that cause fever and eruptions. We suggest that clinical, laboratory, and demographic data may be a clue for predicting the presence of roseola infantum when determining the cause of fever of unknown origin in an outpatient setting.

The disease is sporadic in nature. Unlike with other diseases with eruptions, there is no history of contact with persons suffering from this disease when evaluating children with roseola infantum. The disease is not expected to cause an epidemic. The disease can be seen worldwide, throughout the year $(2,5,21,22)$. The absence of a history of contact in these patients and the fact that it can be observed throughout the year and in a sporadic form, is consistent with literature studies.

Although newborn cases with HHV-6 infection have been reported even though antibodies are passed from the mother, most babies are protected from the disease in the first months of life due to the antibodies passed on from the mother (22). The prevalence of anti-HHV-6-lgG antibody in the mothers of newborns was found to be $71.9 \%$. The rate of passive antibody decline between the second and sixth months is reported as $23.2 \%$ (23). Serological studies have shown that most children have a HHV- 6 infection before the age of three, particularly between 6-15 months (1). Antibody positivity rates among different age groups of HHV- 6 were found to be $69.2 \%$ between 7-12 months, $71.6 \%$ between $13-24$ months and $79.8 \%$ between 3-5 years (23). The HHV-7 infection is observed at a slightly later age than the HHV- 6 infection. About $50 \%$ of children until the age of three, $75 \%$ of children aged 3-6 years, $90 \%$ of adults are seropositive for HHV-7 $(5,24)$. The absence of any cases up to the first two months and the fact that $75 \%$ of the cases are from three months up to 12 months, is consistent with literature studies with regards to it coinciding with the period of passive antibodies decline.

HHV-6 may suppress all bone marrow cell lines. HHV- 6 infection may result in a decrease of MHC type I response on the immune system, increased NK cell activity, suppression of peripheral blood mononuclear cell proliferation, and induction of proinflammatory cytokine response $(24,25)$.
CRP is produced within 4-6 hours after the onset of inflammation or tissue damage. CRP doubles every eight hours before reaching the highest value at around 36 hours (18). The level of CRP is often below $2 \mathrm{mg} / \mathrm{L}$ in healthy individuals, but may rise up to $10 \mathrm{mg} / \mathrm{L}$. It may vary slightly with age, gender, and race. Its half-life is about 19 hours (8).

Acute HHV-6 infection stimulates cellular immunoregulatory mediators (IL-1, INF- $a$, INF- $\gamma$, TNF- $\alpha$ ) and natural killer (NK) cell cytotoxicity $(1,26-29)$. Monocyte and monocyte-derived dendritic cells are targets of HHV- 6 in the pathogenesis and immunosuppressive effect during acute infection $(30,31)$. Increased proinflammatory cytokine secretion such as interleukin $1 \beta$ (IL-1 $\beta)$, tumor necrosis factor- $\alpha$ (TNF- $a$ ) and interferon- $\alpha$ (INF- $\alpha$ ) is observed in peripheral blood mononuclear cells during HHV-6 infection, and NK cell activity is also observed to increase together with IL-15 synthesis. Although HHV- 6 is a potent stimulator of TNF- $\alpha$ and IL-1 $\beta$ in peripheral blood mononuclear cell cultures, HHV- 6 has no effect on IL-6 synthesis $(26,32)$. The CRP level should be below $20 \mathrm{mg} / \mathrm{L}$ to rule out severe infections (16). The mean CRP value was reported as $4.0 \mathrm{mg} / \mathrm{L}$ in our patients. The fact that CRP, the acute phase reactant does not increase despite the presence of fever in all patients, may be the reason why the major CRP stimulant IL-6 cannot be synthesized. As a result, we believe that the increase in CRP despite the presence of fever may be an indirect indicator of primary HHV- 6 infection.

HHV-6 may suppress all bone marrow cell lines $(13,14)$. As a result, neutropenia may first develop, followed by thrombocytopenia $(10,11,33)$. During the first few days of fever in patients with roseola infantum, the mean leucocyte count is around 8-9.0 $\times 10^{9} / \mathrm{L}$, with a neutrophil dominance. The mean leukocyte count at the time of onset of eruptions decreases by 4-6.0 $\mathrm{x}$ $10^{9} / \mathrm{L}$, and relative lymphocytosis (70-90\%) is observed (34). We are of the opinion that the fact that the mean leukocyte count was $7.5 \pm 2.8 \times 10^{\%} / \mathrm{L}$, that some of the patients had fever while the leukocyte count was measured in some during the eruption period suggests that it was an intermediate value.

The mean age of our patients was $11.5 \pm 7.02$. As a result, the mean leukocyte count of a healthy one-year-old child is $11.4 \times 10^{9} / \mathrm{L}$, the neutrophil count is $3.5 \times 10^{9} / \mathrm{L}$, the lymphocyte count is $7.0 \times 10^{9} / \mathrm{L}$ and the monocyte count is $0.6 \times 10^{9} / \mathrm{L}$ (35). The normal value defined for a one year old was found to be low, since the mean leucocyte count was $7.5 \pm 2.8 \times 10^{9} / \mathrm{L}$, neutrophil count was $1.7 \pm 1.30 \times 10^{9} / \mathrm{L}$, lymphocyte count was $5.0 \pm 2.2 \times 10^{9} / \mathrm{L}$ and monocyte count was $0.52 \pm 0.30 \times$ $10^{9} / \mathrm{L}$. Hence, partial bone marrow progenitor cell suppression and a decrease in transient leukocyte counts can be suggested. The normal lymphocyte/neutrophil ratio for a child of one year is approximately (7.0/3.5) 2 (35). Relative lymphocytosis (75\%) can be suggested, as the lymphocyte/neutrophil ratio 
(5.0/1.7) of our patients is about 3. Our study is consistent with the literature studies as a result. IL- 6 usually stimulates neutrophil production from bone marrow progenitor cells together with colony stimulating factors (12). We are of the opinion that transient reductions in leukocyte counts and transient neutropenia (57.5\%) can occur due to the inhibition of IL-6 synthesis during primary HHV- 6 infection and the suppression of bone marrow progenitor cell lines.

HHV-6 has a distinguishable cytopathic effect consisting of the appearance of large refractile mononucleated or multinucleated cells with intracytoplasmic and/or intra-nuclear inclusions. In the culture medium, infected cells demonstrate a some what long half-life, dominated by lytic infection. HHV6 infection also stimulates apoptosis of T cells and leads to the death of the cell through retinoic acid-induced cell death, signals and interferon exchange, as well as mitochondrial membrane potential loss (5). ALT in the cell is found only in the cytosol, whereas AST is found both in the mitochondria and cytosol. Therefore, AST elevation is more prominent in diseases affecting the mitochondria (36). In patients with primary HHV-6 infection and severe neutropenia, AST is reported to be $50 \mathrm{U} / \mathrm{L}$ and ALT $18 \mathrm{U} / \mathrm{L}$, whereas in patients without neutropenia AST is $44 \mathrm{U} / \mathrm{L}$ and ALT $19 \mathrm{U} / \mathrm{L}$ (10). A mean AST of $50 \mathrm{U} / \mathrm{L}$ and ALT of $24 \mathrm{U} / \mathrm{L}$ were detected in our patients. Since AST demonstrates cell lysis/necrosis, AST elevation may be a clue for patients with primary HHV-6 infection affecting the mitochondria.

After the fever falls and the eruptions appear, the disease should be differentiated from other maculopapular eruption diseases such as measles, rubella, scarlet fever, enteroviral infections, and drug reactions (5). Roseola infantum may be very difficult to distinguish from other common viral infections during childhood. Primary infection with HHV-6 or HHV-7 is often indistinguishable from febrile diseases. This difficulty also applies to the early stages of roseola before skin eruptions develop. In the presence of skin eruptions, roseola can be confused with other exanthematous diseases of childhood, particularly measles and rubella. Unlike roseola, the typical symptoms of measles are gastrointestinal complaints, arthralgia, sore throat, low fever and mild disease. On physical examination, the sub-occipital and posterior auricular lymph nodes are detected before the eruptions of rubella occur and continue during the eruption phase. In addition, rubella eruptions start on the face and spread to the torso in a similar manner to measles.

Unlike with roseola, symptoms associated with measles virus infection include high fever, cough, coryza, and conjunctivitis, with concomitant development of skin eruptions.

Roseola may also be confused with the rarely reported scarlet fever seen in children under the age of two. Scarlet fe- ver causes a characteristic sand paper-like skin eruption which occurs concomitantly with fever.

Roseola can be confused with diseases that cause enterovirus infection, particularly in summer and autumn. Enterovirus infections are mostly in the form of hand-foot-mouth disease and the skin eruption is in the form of papulo-vesicles. In addition, fever and rubelliform rash are observed concomitantly.

It may also be difficult to differentiate drug allergies from roseola. Antibiotics are often prescribed for people with roseola fever before skin eruptions are observed. A child with skin eruptions after a fever has subsided is mistakenly described as having a drug allergy. Our patients had no history of drug use.

No similar study has been reported in Turkey about roseola infantum of childhood. Despite the absence of serological and virological (PCR, PCR) evidence of HHV-6 infection in our study, this study was consistent with the studies reported in the literature in terms of age group of the patients, peak age observed, gender and observation throughout the year. This may also be an indirect proof that HHV-6 infection has occurred.

In conclusion, roseola infant should be considered as a cause of fever of unknown origin in children less than three years of age (particularly in infants below the age of 6) who undertook simple laboratory tests and neutropenia, relative lymphocytosis, mild AST elevation and CRP negativity that were detected under emergency conditions.

\section{Acknowledgment}

We would like to thank the Public Health Specialist, Dr. Binali Çatak for his contribution to the research.

Ethics Committe Approval: It was obtained from the Ethics Committee of the Kafkas University Faculty of Medicine, with the date of 11.01.2017 and numbered 80576354-050-99/01.

Informed Consent: Patient consent was not received since this did not entail long term follow-up and required archival studies.

Peer-review: Externally peer-reviewed.

Author Contributions: Concept - ZB; Design - ZB; Supervision - SÜ, DÜÜ; Data Collection and/or Processing - MHA, CB, AA; Analysis and/or Interpretation - ZB; Literature Review - SÜ, DÜÜ; Writing - ZB; Critical Review - All of authors.

Conflict of Interest: The authors have not reported a conflict of interest.

Financial Disclosure: There is no financial support in this study.

\section{References}

1. De Bolle L, Naesens L, De Clerca E. Update on human herpesvirus 6 biology, clinical features, and therapy. Clin Microbiol Rev 2005;18:21745. [CrossRef] 
2. Ward KN. The natural history and laboratory diagnosis of human herpesviruses-6 and -7 infections in the immunocompetent. J Clin Virol 2005;32:183-93. [CrossRef]

3. Bates $M$, Monze $M$, Bima $H$, et al. Predominant human herpesvirus 6 variant $A$ infant infections in an HIV-1 endemic region of Sub-Saharan Africa. J Med Virol 2009;81:779-89. [CrossRef]

4. Pruksananonda $P$, Hall $C B$, Insel RA, et al. Primary human herpesvirus 6 infection in young children. N Engl J Med 1992;326:1445-50. [CrossRef]

5. Caserta MT. Roseola (Human Herpesviruses 6 and 7). In: Kliegman RM, Stanton BF, ST Geme JW, Schor NF, Behrman RE (eds). Nelson Textbook of Pediatrics, 19th ed. Philadelphia (PA): Elsevier Saunders, 2011;15947.

6. Hall $C B$, Long $C E$, Schnabel $K C$, et al. Human herpesvirus- 6 infection in children. A prospective study of complications and reactivation. $N$ Engl J Med 1994;331:432-8. [CrossRef]

7. Caserta MT, Mock DJ, Dewhurst S. Human herpesvirus 6. Clin Infect Dis 2001;33:829-33. [CrossRef]

8. Pepys MB, Hirschfield GM. C-reactive protein: a critical update. J Clin Invest 2003;111:1805-12. [CrossRef]

9. Markanday A. Acute phase reactants in infections: evidence-based review and a guide for clinicians. Open Forum Infect Dis 2015;2:ofv098. [CrossRef]

10. Miura H, Kawamura $Y$, Ozeki E, Ihira M, Ohashi M, Yoshikawa T. Pathogenesis of severe neutropenia in patients with primary human herpesvirus 6B infection. Pediatr Infect Dis J 2015;34:1003-7. [CrossRef]

11. Husain EH, Mullah-Ali A, Al-Sharidah S, Azab AF, Adekile A. Infectious etiologies of transient neutropenia in previously healthy children. Pediatr Infect Dis J 2012;31:575-7. [CrossRef]

12. Abbas AK, Lichtman AH, Pillai S. Cytokines. In: Abbas AK, Lichtman AH, Pillai S (eds). Cellular and molecular immunology (6thed). Philadelphia, PA: Saunders, 2007:267-301.

13. Knox KK, Carrigan DR. In vitro suppression of bone marrow progenitor cell differentiation by human herpesvirus 6 infection. J Infect Dis 1992;165:925-9. [CrossRef]

14. Isomura H, Yamada M, Yoshida $M$, et al. Suppressive effects of human herpesvirus 6 on in vitro colony formation of hematopoietic progenitor cells. J Med Virol 1997;52:406-12. [CrossRef]

15. Hall CB, Caserta MT. Human Herpesviruses 6 and 7 (Roseola, Exanthem Subitum). In: Long SS, Pickering LK, Prober CG (eds). Principles and Practice of Pediatric Infectious Diseases. 4th ed. China: Elsevier Saunders, 2012;1052-9.

16. Van den Bruel A, Thompson MJ, Haj-Hassan T, et al. Diagnostic value of laboratory tests in identifying serious infections in febrile children: systematic review. BMJ 2011;342:d3082. [CrossRef]

17. Lacroix L, Manzano S, Vandertuin L, Hugon F, Galetto-Lacour A, Gervaix A. Impact of the lab-score on antibiotic prescription rate in children with fever without source: a randomized controlled trial. PLoS One 2014;9:e115061. [CrossRef]

18. Andreola B, Bressan S, Callegaro S, Liverani A, Plebani M, Da Dalt L. Procalcitonin and $C$-reactive protein as diagnostic markers of severe bacterial infections in febrile infants and children in the emergency department. Pediatr Infect Dis J 2007;26:672-7. [CrossRef]

19. Tesini BL, Epstein LG, Caserta MT. Clinical impact of primary infection with roseoloviruses. Curr Opin Virol 2014;9:91-6. [CrossRef]

20. Asano Y, Yoshikawa T, Suga S, et al. Clinical features of infants with primary human herpesvirus 6 infection (exanthem subitum, roseola infantum). Pediatrics 1994;93:104-8. [CrossRef]
21. Okuno T, Takahashi K, Balachandra $K$, et al. Seroepidemiology of human herpesvirus 6 infection in normal children and adults. J Clin Microbiol 1989;27:651-3. [CrossRef]

22. Zerr DM, Meier AS, Selke SS, et al. A population-based study of primary human herpesvirus 6 infection. N Engl J Med 2005;352:768-76. [CrossRef]

23. Enders G, Biber M, Meyer G, Helftenbein E. Prevalence of antibodies to human herpesvirus 6 in different age groups, in children with exanthema subitum, other acute exanthematous childhood diseases, Kawasaki syndrome, and acute infections with other herpesviruses and HIV. Infection 1990;18:12-5. [CrossRef]

24. Agut $H$, Bonnafous $P$, Gautheret-Dejean A. Update on infections with human herpesviruses 6A, 6B, and 7. Med Mal Infect 2017;47:83-91.

25. Agut $H$, Bonnafous $P$, Gautheret-Dejean A. Laboratory and clinical aspects of human herpesvirus 6 infections. Clin Microbiol Rev 2015;28:313-35. [CrossRef]

26. Flamand L, Gosselin J, D'Addario $M$, et al. Human herpesvirus 6 induces interleukin-1 beta and tumor necrosis factor alpha, but not interleukin-6, in peripheral blood mononuclear cell cultures. J Virol 1991;65:5105-10. [CrossRef]

27. Flamand L, Stefanescu I, Menezes J. Human herpesvirus-6 enhances natural killer cell cytotoxicity via IL-15. J Clin Invest 1996;97:1373-81. [CrossRef]

28. Kumagai $T$, Yoshikawa $T$, Yoshida $M$, et al. Time course characteristics of human herpesvirus 6 specific cellular immune response and natural killer cell activity in patients with exanthema subitum. J Med Virol 2006;78:792-9. [CrossRef]

29. Takahashi K, Segal E, Kondo $T$, et al. Interferon and natural killer cell activity in patients with exanthem subitum. Pediatr Infect Dis $J$ 1992;11:369-73. [CrossRef]

30. Takemoto M, Imasawa T, Yamanishi K, Mori Y. Role of dendritic cells infected with human herpesvirus 6 in virus transmission to CD4(+) T cells. Virology 2009;385:294-302. [CrossRef]

31. Janelle $M E$, Flamand L. Phenotypic alterations and survival of monocytes following infection by human herpesvirus-6. Arch Virol 2006;151:1603-14. [CrossRef]

32. Gosselin J, Tomolu A, Gallo RC, Flamand L. Interleukin-15 as an activator of natural killer cell-mediated antiviral response. Blood 1999;94:42109. [CrossRef]

33. Hashimoto H, Maruyama H, Fujimoto K, Sakakura T, Seishu S, Okuda $N$. Hematologic findings associated with thrombocytopenia during the acute phase of exanthem subitumconfirmed by primary human herpesvirus-6 infection. J Pediatr Hematol Oncol 2002;24:211-4. [CrossRef]

34. Leach CT. Roseola (Human Herpesviruses 6 and 7). In: Kliegman RM Behrman RE, Jenson HB, Stanton BF (eds). Nelson Textbook of Pediatrics, $16^{\text {th }}$ ed. Philadelphia (PA): WB Saunders, 2007;1380-3.

35. Brugnara $C$. Reference values in infancy and childhood. In: Orkin $S H$ Nathan DG, Ginsburg D, Look AT, Fisher DE, Lux SE( eds). Nathan and Oski's Hematology of Infancy and Childhood 7th ed. Philadelphia: Saunders Elsevier, 2009;1769-96.

36. Nelson DL, Cox MM (eds). Amino acid oxidation and the production of urea (pathways of amino acid degradation). Lehninger Principles of Biochemistry 8th ed. New York: W.H. Freeman and Company, 2013;695730. 